\title{
ANALISIS PENERAPAN AKUNTANSI MUSYARAKAH TERHADAP PSAK 106 PADA BANK SYARIAH X
}

\author{
Muhammad Yusuf \\ Jurusan Akuntansi, Fakultas Ekonomi dan Komunikasi, BINUS University \\ Jln. K.H. Syahdan No. 9, Palmerah, Jakarta Barat 11480
}

\begin{abstract}
Islamic accounting standard is necessary in order to support the development of Islamic banking since it becomes the key to success standard Islamic bank in serving the community. Information provided by Islamic banks can be either financial reports or information of Islamic banking products. Broadly speaking, these products funding and lending of Islamic banks mobilize funds are grouped in a scheme consisting of the principles of Islamic banks are wadi'ah financing and mudarabah financing. The research focuses on the profit and loss sharing scheme, particularly the Musharakah financing. This research is to compare between theory and practice prevailing in the company, especially in the accounting treatment and measurement of the Musharaka Islamic Bank X, about whether or not the accounting treatment in accordance with PSAK 106. Accounting Musharaka. The results of this study suggest that accounting Applied Islamic Bank X, are in accordance with PSAK 106, only in writing the name of the estimates in recording with financing terms should be replaced with Musharaka investment.
\end{abstract}

Keywords: accounting for Musharakah, PSAK 106, Islamic Bank

\begin{abstract}
ABSTRAK
Standar akuntansi syariah sangat diperlukan guna mendukung perkembangan perbankan syariah karena standar tersebut menjadi kunci sukses bank syariah dalam melayani masyarakat. Informasi yang diberikan oleh bank syariah dapat berupa informasi laporan keuangan dan informasi produk-produk perbankan syariah. Secara garis besar, produk-produk penghimpunan dan penyaluran dana bank syariah dikelompokkan dalam pola penghimpunan dana bank syariah terdiri dari prinsip wadi'ah dan mudharabah. Penelitian ini fokus pada pola bagi hasil, khususnya pembiayaan musyarakah. Penelitian ini bertujuan untuk membandingan antara teori dengan praktik yang berlaku di perusahaan, khususnya dalam perlakuan dan pengukuran akuntansi musyarakah pada bank syariah X tentang sesuai atau tidaknya perlakuan akuntansi tersebut dengan PSAK 106., tentang Akuntansi musyarakah. Hasil penelitian ini menunjukkan bahwa penerapan akuntansi musyarakah pada Bank Syariah X telah sesuai dengan PSAK 106. Akan tetapi, hanya pada penulisan nama perkiraaan dalam pencatatannya dengan istilah pembiayaan musyarakah seharusnya diganti dengan investasi musyarakah
\end{abstract}

Kata kunci: akuntansi musyarakah, PSAK 106, bank syariah 


\section{PENDAHULUAN}

Bank syariah menginvestasikan dana yang disimpan pada bank tersebut (dana pemilik bank maupun dana rekening investasi) dengan menggunakan alat investasi yang sesuai dengan syariah Islam. Investasi yang sesuai dengan syariah tersebut meliputi akad Murabahah, Ijarah, Musyarakah, Mudharabah, Salam, dan Istishna. Secara garis besar, produk-produk penghimpunan dan penyaluran dana bank syariah dikelompokkan dalam pola penghimpunan dana bank syariah, terdiri dari prinsip wadi'ah dan mudharabah. Sedangkan penyalurkan dana kepada nasabah, meliputi penyaluran dana dengan pola bagi hasil, terdiri dari pembiayaan mudharabah dan musyarakah. Penyaluran dana dengan pola Ujroh (sewa) terdiri dari pembiayaan ijarah atau ijarah muntahiyyah bit tamlik, serta penyaluran dana dengan pola jual beli terdiri dari pembiayaan murabahah, salam, dan istishna.

Penelitian ini akan berfokus pada pola bagi hasil, khususnya pembiayaan musyarakah. Pengertian musyarakah menurut Yusuf dan Wiroso (2011) adalah akad kerja sama antara para pemilik modal yang mencampurkan modal mereka untuk tujuan mencari keuntungan. Dalam musyarakah mitra dan bank sama-sama menyediakan modal untuk membiayai suatu usaha tertentu, baik yang sudah berjalan maupun yang baru. Selanjutnya, mitra dapat mengembalikan modal tersebut berikut bagi hasil yang telah disepakati secara bertahap atau sekaligus kepada bank. Laba musyarakah dibagi diantara para mitra, baik secara proporsional sesuai dengan modal yang disetorkan (berupa kas dan/atau aktiva lainnya) maupun sesuai nisbah yang disepakati oleh semua mitra. Sedangkan rugi dibebankan secara proporsional, sesuai dengan modal yang disetorkan (berupa kas dan/atau aktiva lainnya).

Oleh karena itu, dalam kaitannya, penghimpunan dana antara bank syariah dengan nasabah pemilik dana (penabung) merupakan hubungan kemitraan karena sesuai dengan prinsip syariah; bahwa bank syariah sebagai pemegang amanah harus ada keterbukaan, kepercayaan, keadilan, dan transparansi, terutama hal-hal yang berkaitan dengan pembagian hasil usaha. Karena nasib para nasabah sangat tergantung pada hasil usaha pengelolahan dana yang dilakukan oleh bank syariah, apa yang dialami oleh bank syariah dapat diketahui oleh para penabung.

Tujuan penelitian ini adalah memperoleh tentang hasil analisis atas prosedur dan penerapan pembiayaan musyarakah yang diterapkan oleh Bank Syariah X dibandingkan dengan PSAK 106. Manfaat penelitian ini adalah memberikan informasi kepada msyarakat, khususnya nasabah bank syariah untuk memberikan keyakinan bahwa penerapan prinsip-prinsip syariah tentang akuntansi musyarakah telah dijalankan sesuai PSAK 106. Maka, penerapan prinsip syariah ini akan berdampak positif terhadap distribusi sumber-sumber ekonomi untuk kepentingan masyarakat karena prinsipprinsip syariah memberikan keseimbangan antara kepentingan pemilik modal (shohibul maal) dengan pengelola dana (mudharib).

\section{Bank Syariah}

Menurut batasan yang terdapat dalam Peraturan Bank Indonesia Nomor 2/8/PBI/2000 pasal 1, pengertian bank syariah adalah:

“Bank umum sebagaimana yang dimaksud dalam Undang-undang Nomor 7 tahun 1992 tentang Perbankan sebagaimana telah diubah dengan Undang-undang Nomor 10 tahun 1998 yang melakukan kegiatan usaha berdasarkan prinsip syariah, termasuk unit usaha syariah dan kantor cabang bank asing yang melakukan kegiatan usaha berdasarkan prinsip syariah. Adapun unit usaha syariah adalah unit kerja di kantor pusat bank konvensional yang berfungsi sebagai kantor induk dari kantor cabang syariah.” 
Perbankan syariah beroperasi atas dasar prinsip-prinsip syariah. Prinsip syariah merupakan aturan dasar atau aturan pokok yang berdasarkan hukum Islam. Prinsip ini menjadi landasan aturan muamalah yang mengatur hubungan antara bank dengan pihak lain dalam rangka penghimpunan dan penyaluran dana serta kegiatan perbankan syariah lainnya.

Menurut Yusuf dan Wiroso (2011), secara garis besar produk-produk penghimpunan dan penyaluran dana bank syariah dikelompokkan dalam: (1) penghimpunan dana bank syariah terdiri dari penghimpunan dana prinsip wadi'ah dan mudharabah; dan (2) penyaluran dana; pola penyalurkan dana kepada nasabah, terdapat 3 (tiga) kelompok, meliputi: (a) penyaluran dana dengan pola bagi hasil: pembiayaan mudharabah dan musyarakah, (b) penyaluran dana dengan pola ujroh (sewa): pembiayaan ijarah atau ijarah muntahiyyah bit tamlik, (c) penyaluran dana dengan pola jual beli: pembiayaan murabahah, salam, dan istishna.

Menurut Antonio (2001), secara umum, terdapat perbedaan antara bank syariah dengan bank konvensional yang menyangkut aspek legal, struktur organisasi, usaha yang dibiayai dan lingkungan kerja (Tabel 1).

Tabel 1. Perbedaan Bank Syariah dan Bank Konvensional

\begin{tabular}{llll}
\multicolumn{1}{c}{ Bank Syariah } & \multicolumn{1}{c}{ Bank Konvensional } \\
\hline 1. & $\begin{array}{l}\text { Berdasarkan prinsip bagi hasil, jual } \\
\text { beli, atau sewa; }\end{array}$ & 1. & Memakai perangkat bunga; \\
2. Profit dan falah oriented; & 2. & Profit oriented; \\
3. $\begin{array}{l}\text { Hubungan dengan nasabah dalam } \\
\text { bentuk hubungan kemitraan; }\end{array}$ & 3. & $\begin{array}{l}\text { Hubungan dengan nasabah dalam } \\
\text { bentuk hubungan debitur-kreditur; }\end{array}$ \\
4. Penghimpunan dan penyaluran dana \\
$\begin{array}{l}\text { harus sesuai dengan fatwa Dewan } \\
\text { Pengawas Syariah. }\end{array}$
\end{tabular}

Sumber: Antonio (2001)

\section{Prinsip Bagi Hasil}

Mekanisme perhitungan bagi hasil yang diterapkan dalam perbankan syariah terdiri dari dua sistem, yaitu: profit sharing dan revenue sharing. Profit sharing adalah perhitungan bagi hasil didasarkan pada hasil bersih dari total pendapatan setelah dikurangi dengan biaya-biaya yang dikeluarkan untuk memperoleh pendapatan tersebut. Pada perbankan syariah istilah yang sering dipakai adalah profit and loss sharing, di mana hal ini dapat diartikan sebagai pembagian antara untung dan rugi dari pendapatan yang diterima atas hasil usaha yang telah dilakukan.

Revenue pada perbankan syariah adalah hasil yang diterima oleh bank dari penyaluran dana (investasi) ke dalam bentuk aktiva produktif, yaitu penempatan dana bank pada pihak lain. Hal ini merupakan selisih atau angka lebih dari aktiva produktif dengan hasil penerimaan bank. Perbankan syariah memperkenalkan sistem pada masyarakat dengan istilah Revenue Sharing, yaitu sistem bagi hasil yang dihitung dari total pendapatan pengelolaan dana tanpa dikurangi dengan biaya pengelolaan dana.

Secara mendasar, perbedaan antara sistem bagi hasil dengan sistem bunga dapat dilihat pada Tabel 2 berikut. 
Tabel 2 Perbedaan sistem bagi hasil dan sistem bunga

\begin{tabular}{|c|c|c|}
\hline Keterangan & Sistem Bagi Hasil & Sistem Bunga \\
\hline Penentuan besarnya hasil & $\begin{array}{l}\text { Penentuan besarnya bagi hasil dibuat } \\
\text { pada waktu akad dengan berpedoman } \\
\text { pada kemungkinan untung-rugi. }\end{array}$ & $\begin{array}{l}\text { Penentuan bunga dibuat pada waktu } \\
\text { akad dengan asumsi harus selalu } \\
\text { untung. }\end{array}$ \\
\hline Yang ditentukan sebelumnya & $\begin{array}{l}\text { Menyepakati besarnya rasio/proporsi } \\
\text { bagi hasil berdasarkan pada jumlah } \\
\text { keuntungan yang diperoleh. }\end{array}$ & $\begin{array}{l}\text { Besarnya persentase (bunga, besarnya } \\
\text { nilai rupiah) berdasarkan pada jumlah } \\
\text { uang (modal) yang dipinjamkan. }\end{array}$ \\
\hline Jika terjadi kerugian & $\begin{array}{l}\text { Ditanggung kedua belah pihak, nasabah } \\
\text { dan lembaga keuangan syariah. }\end{array}$ & $\begin{array}{l}\text { Ditanggung oleh nasabah peminjam } \\
\text { saja. }\end{array}$ \\
\hline Titik perhatian proyek/usaha & $\begin{array}{l}\text { Keberhasilan proyek/usaha jadi } \\
\text { perhatian bersama, nasabah dan bank } \\
\text { syariah. }\end{array}$ & $\begin{array}{l}\text { Besarnya bunga yang harus dibayar } \\
\text { nasabah/pasti diterima bank. }\end{array}$ \\
\hline e. Berapa besarnya & $\begin{array}{l}\text { Proporsi (\%) kali jumlah untung yang } \\
\text { belum diketahui = belum diketahui. }\end{array}$ & $\begin{array}{l}\text { Pasti : (\%) kali jumlah pinjaman yang } \\
\text { telah pasti diketahui. }\end{array}$ \\
\hline f. Status hukum & $\begin{array}{l}\text { Tidak ada yang meragukan keabsahan } \\
\text { bagi hasil, melaksanakan QS. Luqman : } \\
34 \text {. }\end{array}$ & $\begin{array}{l}\text { Eksistensi bunga diragukan (kalau tidak } \\
\text { dikecam) oleh semua agama, termasuk } \\
\text { Islam. Berlawanan dengan QS. Luqman } \\
\text { : } 34 \text {. }\end{array}$ \\
\hline
\end{tabular}

Sumber: Muhammad (2004)

\section{Pembiayaan} adalah:

Pengertian pembiayaan seperti dikutip undang-undang No.10 tahun 1998 pasal 1 angka 12,

"Pembiayaan berdasarkan prinsip syariah merupakan penyediaan uang atau tagihan yang dipersamakan dengan itu berdasarkan persetujuan atau kesepakatan antara bank dengan pihak lain yang mewajibkan pihak yang dibiayai untuk mengembalikan uang tagihan tersebut setelah jangka waktu tertentu dengan imbalan atau bagi hasil.”

Sedangkan menurut Muhammad (2005) pengertian pembiayaan adalah:

"Pendanaan yang diberikan oleh suatu pihak kepada pihak lain untuk mendukung investasi yang telah direncanakan, baik dilakukan sendiri maupun lembaga. Dengan kata lain, pembiayaan adalah pendanaan yang dikeluarkan untuk mendukung investasi yang telah direncanakan" (p. 17).

\section{Pembiayaan Musyarakah (Kerjasama Modal Usaha)} berikut:

Di dalam kitab Bidayatul Mujtahid II, hlm 253-257, musyarakah didefinisikan sebagai

"Musyarakah adalah akad kerja sama antara dua pihak atau lebih untuk suatu usaha tertentu dimana masing-masing pihak memberikan konstribusi dana dengan kesepakatan bahwa keuntungan dan risiko akan ditanggung bersama sesuai dengan kesepakatan” (p. 253-257) 
Berdasarkan PSAK 106 (Paragraf 04), musyarakah didefinisikan sebagai berikut:

"Musyarakah adalah akad kerja sama antara dua pihak atau lebih untuk suatu usaha tertentu dimana masing-masing pihak memberikan konstribusi dana dengan ketentuan bahwa keuntungan dibagi berdasarkan kesepakatan sedangkan kerugian berdasarkan porsi konstribusi dana. Dana tersebut meliputi kas atau aset non kas yang diperkenankan oleh syariah.”

Jenis-jenis musyarakah terdiri dari musyarakah permanen dan musyarakah menurun. Musyarakah permanen, menurut PSAK No.106 (Paragraf 04), adalah musyarakah dengan ketentuan pembagian dana setiap mitra ditentukan sesuai akad dan jumlahnya tetap hingga akhir masa akad. Lebih lanjut, menurut PSAK No.106 (Paragraf 04), musyarakah menurun adalah musyarakah dengan ketentuan bagian dana salah satu mitra akan dialihkan secara bertahap kepada mitra lainnya sehingga bagian dananya akan menurun pada akhir masa akad mitra lain tersebut dan akan menjadi pemilik penuh usaha tersebut.

Karakteristik musyarakah sebagaimana yang tertuang dalam PSAK 106 tentang akuntansi musyarakah, adalah: (1) para mitra bersama-sama menyediakan dana untuk mendanai suatu usaha tertentu dalam musyarakah, baik usaha yang sudah berjalan maupun yang baru; (2) investasi musyarakah dapat diberikan dalam bentuk kas, setara kas atau aset nonkas; dan (3) keuntungan usaha musyarakah dibagi antara para mitra secara proporsional sesuai dengan dana yang disetorkan (baik berupa kas maupun aset nonkas) atau sesuai dengan nisbah yang disepakati oleh para mitra. Sedangkan kerugian, dibebankan secara proporsional sesuai dengan dana yang disetorkan (baik berupa kas maupun aset nonkas).

Dalam PSAK No.106 dijelaskan bahwa untuk pertanggungjawaban pengelolaan usaha musyarakah dan sebagai dasar penentuan bagi hasil, mitra aktif atau pihak yang mengelola usaha musyarakah harus membuat catatan akuntansi yang terpisah untuk usaha musyarakah tersebut.

Dalam akuntansi untuk mitra aktif, investasi musyarakah diakui pada saat penyerahan kas atau aset nonkas untuk usaha musyarakah. Pengukuran investasi musyarakah dalam bentuk: (1) kas dinilai sebesar jumlah yang diserahkan; dan (2) aset nonkas dinilai sebesar nilai wajar dan jika terdapat selisih antara nilai wajar dan nilai buku aset nonkas, selisih tersebut diakui sebagai selisih penilaian aset musyarakah dalam ekuitas. Selisih penilaian aset musyarakah tersebut diamortisasi selama masa akad musyarakah. (Paragraf 15)

Pendapatan usaha musyarakah yang menjadi hak mira aktif diakui sebesar haknya sesuai dengan kesepakatan atas pendapatan usaha musyarakah. Sedangkan pendapatan usaha untuk mitra pasif diakui sebagai hak pihak mitra pasif atas bagi hasil dan kewajiban (Paragraf 23). Kerugian investasi musyarakah diakui sesuai dengan porsi masing-masing mitra dan mengurangi nilai aset musyarakah (Paragaf 24). Jika kerugian akibat kelalaian atau kesalahan mitra aktif atau pengelola usaha, kerugian tersebut ditanggung oleh mitra aktif atau pengelola usaha musyarakah (Paragraf 25).

Dalam akuntansi untuk mitra pasif, investasi musyarakah diakui pada saat pembayaran kas atau penyerahan aset nonkas kepada mitra aktif (Paragraf 27). Pengukuran investasi musyarakah dalam bentuk: (1) kas dinilai sebesar jumlah yang diserahkan; dan (2) aset non kas dinilai sebesar nilai wajar; dan jika terdapat selisih antara nilai wajar dan nilai tercatat aset nonkas, selisih tersebut diakui sebagai keuntungan tangguhan dan diamortisasi selama masa akad atau kerugian pada saat terjadinya (Paragraf 28).

Pendapatan usaha investasi musyarakah diakui sebesar bagian mitra pasif sesuai kesepakatan. Sedangkan kerugian investasi musyarakah diakui dengan porsi dana (Paragraf 34). 
Dalam penyajian musyarakah, mitra aktif menyajikan hal-hal yang terkait usaha musyarakah dalam laporan keuangan, yaitu: (1) kas atau aset nonkas yang disisihkan oleh mitra aktif dan yang diterima dari mitra pasif disajikan sebagai investasi musyarakah; (2) aset musyarakah yang diterima dari mitra pasif disajikan sebagai unsur dana syirkah temporer untuk; dan (3) selisih penilaian asset musyarakah, bila ada disajikan sebagai unsur ekuitas (Paragraf 35).

Sementara itu, mitra pasif menyajikan hal-hal yang terkait usaha musyarakah dalam laporan keuangan, yaitu: (1) kas atau aset nonkas yang diserahkan kepada mitra aktif disajikan sebagai investasi musyarakah; dan (2) keuntungan tangguhan dari selisih penilaian aset nonkas yang diserahkan pada nilai wajar disajikan sebagai pos lawan (contra account) dari investasi musyarakah (Paragraf 36).

Dalam pengungkapan musyarakah, mitra mengungkapkan hal-hal yang terkait transaksi musyarakah, tetapi tidak terbatas pada: (1) isi kesepakatan utama usaha musyarakah, seperti porsi dana, pembagian hasil usaha, aktivitas usaha musyarakah dan lain-lain; dan (2) pengusaha musyarakah jika tidak ada mitra aktif.

Musyarakah dalam aplikasi perbankan syariah dapat berbentuk: (1) pembiayaan proyek, yaitu nasabah dan bank syariah sama-sama menyediakan dana untuk membiayai proyek tersebut. Setelah proyek selesai, nasabah mengembalikan dana yang digunakan beserta bagi hasil yang telah disepakati pada awal perjanjian (ijab qabul). (2) Modal ventura, yakni penanaman modal, dilakukan oleh bank syariah untuk jangka waktu tertentu, dan setelah itu Bank melakukan divestasi atau menjual bagian sahamnya kepada pemegang saham perusahaan.

\section{METODE}

Penelitian ini menggunakan jenis penelitian evaluasi dan menggunakan standar PSAK No.106 sebagai dasar untuk mengevaluasi proses perlakuan akuntansi atas pembiayaan musyarakah. Sifat penelitian ini adalah studi kasus. Penulis mengunakan sifat penelitian studi kasus, di mana sifat penelitian ini tidak hanya memberikan gambaran yang sistematis, akurat mengenai fakta, tetapi juga mempelajari suatu kasus secara lebih terperinci di dalam suatu objek penelitian serta mendapatkan makna dan implikasi dari suatu masalah atau kasus yang ingin dipecahkan. Peneliti menggunakan satu kasus, yaitu transaksi pembiayaan musyarakah, kemudian disesuaikan dengan pengakuan, pengukuran, penyajian, dan pengungkapan terhadap PSAK No.106.

Adapun teknik pengumpulan data yang penulis lakukan terdiri dari data primer dan data sekunder. Data primer yang penulis kumpulkan yaitu didapat dengan datang langsung ke Bank Syariah $\mathrm{X}$. Penulis mengumpulkan data mengenai bagaimana kegiatan pembiayaan musyarakah, syarat, prosedur dan kebijakan pemberian pembiayaan musyarakah, serta bagaimana pengakuan dan pengukuran akuntansi dari pembiayaan musyarakah, data laporan keuangan yang berhubungan dengan pembiayaan musyarakah, serta sejarah perusahaan, struktur organisasi, dan perkembangan pembiayaan musyarakah di Bank Syariah X. Sedangkan, data sekunder yang penulis kumpulkan didapat dari berbagai media informasi baik cetak maupun elektronik, berupa buku-buku, koran, jurnal, Internet dan lain-lain.

Jenis dan sumber data yang digunakan penulis adalah dengan menggunakan metode kualitatif deskriptif. Tujuan dari penelitian kualitatif deskriftif ini adalah untuk membuat depenelitian, gambaran atau lukisan secara sistematis, faktual dan akurat mengenai fakta-fakta dan sifat-sifat dari objek penelitian. Penulis akan menguraikan secara menyeluruh tentang pengakuan, pengukuran, penyajian dan pengungkapan akuntansi pembiayaan musyarakah, lalu membandingkan dengan teori-teori yang berhubungan dengan Pernyataan Standar Akuntansi Keuangan (PSAK) No.106. 
Metode analisis data yang digunakan dalam pembahasan penelitian ini adalah metode evaluasi. Penelitian evaluasi adalah penelitian yang membandingkan suatu kejadian, kegiatan, dan produk dengan standar yang telah diterapkan. Dalam pembahasan penelitian ini, penulis mempelajari dan manganalisis proses dan pelaksanaan atas perlakuan akuntansi pembiayaan musyarakah yang meliputi pengakuan, pengukuran, penyajian, dan pengungkapan untuk Bank Syariah X selaku pengelola dana.

\section{HASIL DAN PEMBAHASAN}

Produk pembiayaan musyarakah yang diterapkan pada Bank Syariah X, meliputi pembiayaan musyarakah permanen dan menurun.

\section{Pembiayaan musyarakah permanen}

Pembiayaan musyarakah antara Bank Syariah X dengan Universitas $\mathrm{X}$ yang bergerak di bidang pendidikan dengan modal yang diperlukan sebesar Rp. 80.000.000.000. Modal yang dimiliki Universitas X sebesar Rp. 59.000.000.000 dan bank sebesar Rp. 21.000.000.000 dalam kesepakatan awal antara Bank Syariah $\mathrm{X}$ dan Universitas X dengan asumsi pembiayaan dilakukan dalam jangka waktu 8 tahun yaitu terhitung 1 Maret 2004 s/d 1 Maret 2012. Porsi pembagian pendapatan bagi hasil yang disepakati adalah 30\% untuk Bank dan 70\% untuk nasabah. Pembagian bagi hasil atas keuntungan adalah setiap tanggal 31 Agustus, yang diperoleh dari pendapatan penerimaan uang gedung yang diterima Universitas $\mathrm{X}$ dari para mahasiswa. Dalam 8 tahun terakhir diproyeksikan besarnya pendapatan uang gedung yang diterima Universitas $\mathrm{X}$ adalah sebagai berikut: tahun pertama, Agustus 2005; kedua, Rp. 2.500.000.000; ketiga, Agustus 2006, Rp. 3.000.000.000; keempat, Agustus 2007, Rp. 3.500.000.000; kelima, Agustus 2008, Rp. 3.000.000.000; keenam, Agustus 2009, Rp. 4.000.000.000; ketujuh, Agustus 2010, Rp. 3.500.000.000; kedelapan, Agustus 2011, Rp. 4.000.000.000; dan kesemnilan, Agustus 2012, Rp. 4.500.000.000

Pada pelaksanaan awal pembiayaan ini, Universitas X dikenakan biaya administrasi sebesar Rp. 3.000.000 dan pembayaran notaris untuk pengesahan usaha pembiayaan musyarakah ini sebesar Rp. 4.000.000 penyelesaian perhitungan bagi hasil dan pengakuan pendapatan dalam pembiayaan musyarakah permanent dengan tabel perhitungan seperti pada Tabel 3.

Tabel 3 Pembiayaan musyarakah permanent Bank Syariah X

\begin{tabular}{|c|c|c|c|c|c|c|}
\hline \multirow{2}{*}{ Tahun } & \multicolumn{2}{|c|}{ Konstribusi modal } & \multirow[t]{2}{*}{ Sub Total } & \multirow{2}{*}{$\begin{array}{c}\text { Penerimaan } \\
\text { Uang } \\
\text { Gedung }\end{array}$} & \multicolumn{2}{|c|}{ Konstribusi Nasabah (\%) } \\
\hline & Bank Syariah & Universitas X & & & Bank Syariah & Universitas X \\
\hline 1 Maret 04 & $21,000,000$ & $59,000,000$ & $80,000,000$ & & $30 \%$ & $70 \%$ \\
\hline 31 Agustus 05 & & & & $2,500,000$ & 750,000 & $1,750,000$ \\
\hline 31 Agustus 06 & & & & $3,000,000$ & 900,000 & $2,100,000$ \\
\hline 31 Agustus 07 & & & & $3,500,000$ & $1,050,000$ & $2,450,000$ \\
\hline 31 Agustus 08 & & & & $3,000,000$ & 900,000 & $2,100,000$ \\
\hline 31 Agustus 09 & & & & $4,000,000$ & $1,200,000$ & $2,800,000$ \\
\hline 31 Agustus 10 & & & & $3,500,000$ & $1,050,000$ & $2,450,000$ \\
\hline 30 Agustus 11 & & & & $4,000,000$ & $1,200,000$ & $2,800,000$ \\
\hline 31 Agustus 12 & $(21,000,000)$ & & & $4,500,000$ & $1,350,000$ & $3,150,000$ \\
\hline Total & & & & $28,000,000$ & $8,400,000$ & $19,600,000$ \\
\hline
\end{tabular}

Sumber: Bank Syariah X 
Pada kasus di atas, diasumsikan bahwa tidak terdapat kerugian, tetapi adanya penurunan dalam penerimaan uang gedung pada periode tertentu yang mengkibatkan pendapatan bagi hasil menurun. Pencatatan akuntansi untuk kasus di atas adalah sebagai berikut:

a) Pencatatan pada saat pembiayaan musyarakah diberikan kepada nasabah:

Dr. Pembiayaan musyarakah yang diberikan $\quad$ Rp 21.000.000.000

Cr. Kas/Rekening giro nasabah $\quad 21.000 .000 .000$

b) Pencatatan atas pembebanan biaya yang dikeluarkan pada saat akad:
Dr. Rekening giro nasabah
Cr. Pendapatan administrasi
Rp 7.000.000
Cr. Rekening notaris
3.000 .000
4.000 .000

c) Pencatatan atas penerimaan pendapatan bagi hasil pada 31 Agustus 2005:
Dr. Kas
Cr. Pendapatan bagi hasil
Rp 750.000.000
750.000 .000

d) Pencatatan atas pelunasan pembiayaan musyarakah:
Dr. Kas
Rp 21.000.000.000
Cr. Pembiayaan musyarakah yang diberikan
21.000.000.000

Apabila pada tanggal 31 Agustus 2012 pendapatan atas bagi hasil yang belum diteima oleh bank, maka bank akan mencatat bagi hasil tersebut sebagai piutang mitra kepada bank.

Pencatatan atas bagian bank yang belum diterima setelah akad berakhir:
Dr. Piutang (musyarakah)
Rp 1.350.000.000
Cr. Pendapatan (musyarakah)
1.350.000.000

Pencatatan atas pelunasan hutang oleh mitra bank pada tanggal 31 Agustus 2008:
Dr. Kas
Cr. Piutang (musyarakah)
Rp 1.350.000.000
1.350 .000 .000

\section{Pembiayaan Musyarakah Menurun}

Pembiayaan musyarakah menurun tidak jauh berbeda dalam pencatatan akuntansinya dengan musyarakah permanen, hanya saja pendapatan bagi hasil dan porsi modal bank akan semakin menurun dari tahun ke tahun hingga porsi modal musyarakah menjadi nol. Sebagai contoh, penyertaan modal pada awal akad dan penerimaan uang gedung yang diterima oleh universitas X (mitra usaha) diasumsikan sama dengan nilai yang ada pada kasus musyarakah permanent sebelumnya. Namun untuk porsi modal musyarakah dari tahun ke tahun yang telah disepakati bersama antara Bank Syariah $\mathrm{X}$ dengan Universitas $\mathrm{X}$ adalah seperti pada Tabel 4.

Tabel 4 Porsi modal musyarakah yang telah disepakati

\begin{tabular}{ccc}
\hline Tahun & Bank Syariah X & Universitas X \\
\hline 1 & 21.000 .000 .000 & 59.000 .000 .000 \\
2 & 18.000 .000 .000 & 62.000 .000 .000 \\
3 & 15.000 .000 .000 & 65.000 .000 .000 \\
4 & 12.000 .000 .000 & 68.000 .000 .000 \\
5 & 9.000 .000 .000 & 71.000 .000 .000 \\
6 & 6.000 .000 .000 & 74.000 .000 .000 \\
7 & 3.000 .000 .000 & 77.000 .000 .000 \\
8 & 0 & 80.000 .000 .000 \\
\hline
\end{tabular}

Sumber: bank Syariah X 
Tabel 5 Pembiayaan Musyarakah Menurun pada Bank syariah X (nisbah berdasarkan porsi modal)

Dalam Ribuan Rupiah

\begin{tabular}{|c|c|c|c|c|c|c|c|}
\hline \multicolumn{2}{|c|}{ Konstribusi Modal (Rupiah) } & \multirow{2}{*}{ Total } & \multirow{2}{*}{$\begin{array}{l}\text { Penerimaan } \\
\text { Uang Gedung }\end{array}$} & & \multicolumn{3}{|c|}{ Konstribusi Nisbah } \\
\hline Bank Syariah & Universitas X & & & & $\begin{array}{l}\text { Bank } \\
\text { Syariah }\end{array}$ & & Universitas X \\
\hline $21,000,000$ & $59,000,000$ & $80,000,000$ & $2,500,000$ & 35 & 875,000 & 65 & $1,625,000$ \\
\hline $18,000,000$ & $62,000,000$ & $80,000,000$ & $3,000,000$ & 30 & 900,000 & 70 & $2,100,000$ \\
\hline $15,000,000$ & $65,000,000$ & $80,000,000$ & $3,500,000$ & 25 & 875,000 & 75 & $2,625,000$ \\
\hline $12,000,000$ & $68,000,000$ & $80,000,000$ & $3,000,000$ & 20 & 600,000 & 80 & $2,400,000$ \\
\hline $9,000,000$ & $71,000,000$ & $80,000,000$ & $4,000,000$ & 15 & 600,000 & 85 & $3,400,000$ \\
\hline $6,000,000$ & $74,000,000$ & $80,000,000$ & $3,500,000$ & 10 & 350,000 & 90 & $3,150,000$ \\
\hline \multirow[t]{3}{*}{$3,000,000$} & $77,000,000$ & $80,000,000$ & $4,000,000$ & 5 & 200,000 & 95 & $3,800,000$ \\
\hline & $80,000,000$ & $80,000,000$ & $4,500,000$ & & & 100 & $4,500,000$ \\
\hline & & & $28,000,000$ & & $4,400,000$ & & $23,600,000$ \\
\hline
\end{tabular}

Sumber: Bank Syariah X

Pencatatan akuntansi untuk transaksi di atas dan pengakuan pendapatan yang diterima bank akan semakin menurun dikarenakan nisbah bagi hasil untuk bank menurun setiap tahunnya hingga akhir dan porsi modal mitra menjadi $100 \%$ pada saat akad diakhiri.

Pencatatan pada saat pembiayaan musyarakah diberikan kepada nasabah:
Dr. Pembiayaan musyarakah yang diberikan
Rp 21.000.000.000
Cr. Kas/Rekening giro nasabah
21.000.000.000

Pencatatan atas pembebanan biaya yang dikeluarkan pada saat awal akad:
Dr. Rekening giro nasabah
Cr. Pendapatan administrasi
Rp 7.000.000.000
Cr. Rekening notaris
3.000 .000 .000
4.000.000.000

Pencatatan atas penerimaan pendapatan bagi hasil pada tanggal 31 Agustus 2005 beserta modal pembiayaan musyarakah yang dikembalikan pada tahun pertama:
Dr. Kas
Cr. Pendapatan bagi hasil musyarakah
Rp 3.875.000.000
Cr. Pembiayaan musyarakah yang diberikan
875.000 .000
3.000 .000 .000

Tabel 6 Pembiayaan musyarakah menurun pada Bank Syariah X

(nisbah berdasarkan porsi presentase bagi hasil)

\begin{tabular}{|c|c|c|c|c|c|c|c|c|}
\hline Th & \multicolumn{2}{|c|}{ Konstribusi Modal } & Total & $\begin{array}{l}\text { Penerimaan } \\
\text { Uang Gedung }\end{array}$ & & \multicolumn{3}{|c|}{ Konstribusi Nisbah (\%) } \\
\hline 1 & $21,000,000$ & $59,000,000$ & $80,000,000$ & $2,500,000$ & 30 & 750,000 & 70 & $1,750,000$ \\
\hline 2 & $18,000,000$ & $62,000,000$ & $80,000,000$ & $3,000,000$ & 25 & 750,000 & 75 & $2,250,000$ \\
\hline 3 & $15,000,000$ & $65,000,000$ & $80,000,000$ & $3,500,000$ & 20 & 700,000 & 80 & $2,800,000$ \\
\hline 6 & $6,000,000$ & $74,000,000$ & $80,000,000$ & $3,500,000$ & 5 & 175,000 & 95 & $3,325,000$ \\
\hline 7 & $3,000,000$ & $77,000,000$ & $80,000,000$ & $4,000,000$ & & & 100 & $4,000,000$ \\
\hline \multirow[t]{2}{*}{8} & & $80,000,000$ & $80,000,000$ & $4,500,000$ & & & & $4,500,000$ \\
\hline & & & & $28,000,000$ & & $3,225,000$ & & $24,775,000$ \\
\hline
\end{tabular}

Sumber : Bank Syariah X 
Pencatatan pada saat pembiayaan musyarakah diberikan kepada nasabah:
Dr. Pembiayaan musyarakah yang diberikan
Rp 21.000.000.000
Cr. Kas/Rekening giro nasabah
Rp 21.000.000.000

Pencatatan atas pembebanan biaya yang dikeluarkan pada saat awal akad:
Dr. Rekening giro nasabah
Rp 7.000.000
Cr. Pendapatan administrasi
Rp 3.000.000
Cr. Rekening notaris
Rp 4.000.000

Pencatatan atas penerimaan pendapatan bagi hasil pada tanggal 31 Agustus 2005 beserta modal pembiayaan musyarakah yang dikembalikan pada tahun pertama:
Dr. Kas
Cr. Pendapatan bagi hasil musyarakah
Rp 3.750.000.000
Cr. Pembiayaan musyarakah yang diberikan
Rp 750.000.000
Rp 3.000.000.000

Untuk penyesuaian itu sendiri disesuaikan dengan kualitas pembiayaan berdasarkan penelaahan atas masing-masing saldo pembiayaan, namun untuk kerugian yang terjadi dalam pembiayaan musyarakah telah sesuai dengan PSAK 106. yaitu ditanggung berdasarkan porsi modal yang disetorkan pada tahun terjadinya kerugian.

\section{Analisis Penerapan Akuntansi Musyarakah pada Bank Syariah X dengan PSAK 106}

Penulis mencoba menganalisis kesesuaian perlakuan akuntansi atas transaksi pembiayaan musyarakah yang terjadi di Bank Syariah X terhadap PSAK No.106, di mana pada kasus ini Bank Syariah X bertindak sebagai mitra pasif dari suatu kerjasama pembiayaan musyarakah.

\section{Pengakuan}

Analisis pengakuan atas pembiayaan musyarakah adalah sebagai berikut:

Pencatatan pada saat pembiayaan musyarakah diberikan kepada nasabah:
Dr. Pembiayaan musyarakah yang diberikan
Rp 21.000.000.000
Cr. Kas/Rekening giro nasabah
$\mathrm{Rp} 21.000 .000 .000$

Investasi Musyarakah yang disepakati antara Bank dengan Universitas X diakui pihak bank pada saat pembayaran kas kepada Universitas X yaitu sebesar Rp. 21.000.000.000. Hal ini sesuai dengan PSAK No.106 (Paragraf 27).

Pencatatan atas pembebanan biaya yang dikeluarkan pada saat akad:
Dr. Rekening giro nasabah
Cr. Pendapatan administrasi
Rp 7.000.000
Cr. Rekening notaris
Rp 3.000.000
Rp 4.000.000

Dalam rangka akad musyarakah ada biaya-biaya yang harus dikeluarkan oleh debitur untuk menentukan kelayakan akad tersebut dan tidak dapat diakui sebagai bagian dari pembiayaan musyarakah kecuali ada persetujuan dari seluruh mitra, yaitu sebesar Rp. 7.000.000. Hal ini sesuai dengan PSAK No.106 (Paragraf 30).

Pencatatan atas penerimaan pendapatan bagi hasil pada 31 Agustus 2005:
Dr. Kas
Rp 750.000.000
Cr. Pendapatan bagi hasil
Rp 750.000.000

Laba masing-masing pihak ditentukan dengan kesepakatan bersama berdasarkan nisbah bagi hasil yang disetujui pada awal akad. Pada bulan Agustus 2005 bank menerima pendapatan dari 
universitas X sebesar Rp. 750.000 .000 maka bank langsung mengakui laba pada periode tersebut. Pengakuan ini sesuai dengan PSAK No106 (Paragraf 34).

Pencatatan atas bagian bank yang belum diterima setelah akad berakhir:
Dr. Piutang (musyarakah)
Rp 1.350.000.000
Cr. Pendapatan (musyarakah)
Rp 1.350.000.000

Bagian bank yang belum diterima pada akhir akad diakui sebagai piutang sebesar Rp. 1.350.000.000. Hal ini sesuai dengan PSAK No.106 (Paragraf 33).

\section{Pengukuran}

Analisis pengukuran atas pembiayaan musyarakah sebagai berikut.

Pencatatan pada saat pembiayaan musyarakah diberikan kepada nasabah:
Dr. Pembiayaan musyarakah yang diberikan
Rp 21.000.000.000
Cr. Kas/Rekening giro nasabah
Rp 21.000.000.000

Bank mengukur pembiayaan musyarakah dalam bentuk kas atau uang tunai dan dinilai sebesar uang yang dibayarkan kepada universitas X, yaitu senilai Rp. 21.000.000.000. Hal ini sesuai dengan PSAK No.106 (Paragraf 28).

Pencatatan atas pelunasan pembiayaan musyarakah:
Dr. Kas
Cr. Pembiayaan musyarakah yang diberikan

Rp 21.000.000.000

Rp 21.000.000.000

Pengembalian dana bank atas investasi musyarakah pada akhir akad diukur sebesar jumlah kas atau uang tunai yang dibayarkan pada awal akad yaitu sebesar Rp. 21.000.000.000. Hal ini sesuai dengan PSAK No.106 (Paragraf 31).

Pencatatan atas penerimaan pendapatan bagi hasil pada tanggal 31 Agustus 2005 beserta modal pembiayaan musyarakah yang dikembalikan pada tahun pertama:
Dr. Kas
Rp 3.750.000.000
Cr. Pendapatan bagi hasil musyarakah
Rp 750.000 .000
Cr. Pembiayaan musyarakah yang diberikan
Rp 3.000.000.000

Pengembalian dana bank atas investasi musyarakah menurun diukur sebesar jumlah kas yang disetorkan pada awal akad dikurangi jumlah pengembalian dari mitra aktif dan kerugian, yaitu sebesar Rp. 21.000.000.000 yang dikembalikan secara bertahap selama 8 tahun, dimana pertahunnya modal bank dikembalikan sebesar Rp. 3.000 .000 dan ditambah dengan pendapatan bagi hasil pada tahun tersebut. Hal ini sesuai dengan PSAK No.106 (Paragraf 32).

\section{Penyajian}

Analisis penyajian pembiayaan musyarakah sebagai berikut.

Pencatatan pada saat pembiayaan musyarakah diberikan kepada nasabah:
Dr. Pembiayaan musyarakah yang diberikan
Rp 21.000.000.000
Cr. Kas/Rekening giro nasabah
Rp 21.000.000.000

Pada saaat realisasi pembiayaan musyarakah, pihak bank menyajikan pencatatan dengan mendebet pembiayaan musyarakah yang diberikan sebesar Rp. 21.000.000.000 dan mengkredit kas atau rekening giro sebesar Rp. 21.000.000.000. Hal ini tidak sesuai dengan PSAK No.106 (Paragraf 
36), seharusnya pembiayaan musyarakah yang diberikan dicatat dalam jurnal sebagai investasi musyarakah.

\section{Pengungkapan}

Analisis pengungkapan pembiayaan musyarakah sebagai berikut.

Konsistensi kesesuaian perlakuan akuntansi atas transaksi pembiayaan musyarakah dengan PSAK No.106 pada Bank Syariah X dapat dilihat pada Tabel 7.

\section{Konsistensi Kesesuaian Penerapan Akuntansi Pembiayaan Musyarakah di Bank Syariah X dengan PSAK 106}

Hasil rangkuman kesesuian penerapan Akuntansi pembiayaan Musyarakah dengan PSAK 106 tertera dalam Tabel 7.

Tabel 7 Konsistensi kesesuaian PSAK No.106 dengan penerapan di Bank Syariah X

\begin{tabular}{|c|c|c|c|}
\hline \multirow{2}{*}{ No } & \multirow{2}{*}{ PSAK No.106 } & \multirow{2}{*}{ Bank Syariah X } & \multirow{2}{*}{$\begin{array}{c}\text { Hasil Analisis } \\
\text { Sesuai }\end{array}$} \\
\hline & & & \\
\hline \multicolumn{3}{|c|}{$\begin{array}{c}\text { Pengakuan } \\
\end{array}$} & Tidak Sesuai \\
\hline 1 & $\begin{array}{l}\text { Investasi musyarakah diakui pada saat } \\
\text { pembayaran kas atau penyerahan asset } \\
\text { non kas kepada mitra aktif }\end{array}$ & $\begin{array}{l}\text { Investasi Musyarakah yang disepakati } \\
\text { antara Bank dengan Universitas X diakui } \\
\text { pihak bank pada saat pembayaran kas } \\
\text { kepada Universitas X }\end{array}$ & Sesuai \\
\hline 2 & $\begin{array}{l}\text { Biaya yang terjadi akibat akad } \\
\text { musyarakah (misal, biaya studi } \\
\text { kelayakan) tidak dapat diakui sebagai } \\
\text { bagian investasi musyarakah kecuali } \\
\text { ada persetujuan dari seluruh mitra. }\end{array}$ & $\begin{array}{l}\text { Dalam rangka akad musyarakah ada biaya- } \\
\text { biaya yang harus dikeluarkan oleh debitur } \\
\text { untuk menentukan kelayakan akad tersebut } \\
\text { dan tidak dapat diakui sebagai bagian dari } \\
\text { pembiayaan musyarakah. }\end{array}$ & Sesuai \\
\hline \multicolumn{3}{|c|}{ Pengukuran } & \\
\hline 1 & $\begin{array}{l}\text { Pengukuran investasi musyarakah } \\
\text { dalam bentuk kas dinilai sebesar jumlah } \\
\text { yang dbayarkan }\end{array}$ & $\begin{array}{l}\text { Bank mengukur pembiayaan musyarakah } \\
\text { dalam bentuk kas atau uang tunai dengan } \\
\text { satuan rupiah dan dinilai sebesar uang yang } \\
\text { dibayarkan kepada universitas X }\end{array}$ & Sesuai \\
\hline \multirow[t]{2}{*}{2} & $\begin{array}{l}\text { Bagian mitra pasif atas investasi } \\
\text { musyarakah dengan pengembalian dana } \\
\text { mitra pasif diakhir akad dinilai sebesar } \\
\text { jumlah kas yang dibayarkan untuk } \\
\text { usaha musyarakah pada awal akad } \\
\text { dikurangi dengan kerugian (jika ada) }\end{array}$ & $\begin{array}{l}\text { Pengembalian dana bank atas investasi } \\
\text { musyarakah pada akhir akad diukur sebesar } \\
\text { jumlah kas atau uang tunai yang dibayarkan } \\
\text { pada awal akad }\end{array}$ & Sesuai \\
\hline & \multicolumn{2}{|c|}{ Penyajian } & \\
\hline \multirow[t]{2}{*}{1} & $\begin{array}{l}\text { Kas atau asset non kas yang diserahkan } \\
\text { kepada mitra aktif disajikan sebagai } \\
\text { investasi musyarakah. }\end{array}$ & $\begin{array}{l}\text { Pada saat realisasi pembiayaan } \\
\text { musyarakah, pihak bank menyajikan } \\
\text { pencatatan dengan mendebet pembiayaan } \\
\text { musyarakah dan mengkredit kas atau } \\
\text { rekening giro }\end{array}$ & Tidak Sesuai \\
\hline & \multicolumn{2}{|c|}{ Pengungkapan } & \\
\hline 1 & $\begin{array}{l}\text { Mitra mengungkapkan hal-hal yang } \\
\text { terkait transaksi musyarakah }\end{array}$ & $\begin{array}{l}\text { Dalam laporan keuangan bank } \\
\text { mengungkapkan besarnya jumlah porsi } \\
\text { dana pembiayaan musyarakah, pembagian } \\
\text { hasil usaha, aktivitas usaha musyarakah dan } \\
\text { lain-lain. }\end{array}$ & Sesuai \\
\hline
\end{tabular}




\section{PENUTUP}

Dari hasil analisis dan pembahasan, maka dapat disimpulkan bahwa: (1) perlakuan akuntansi investasi musyarakah di Bank Syariah X, telah sesuai dengan PSAK No.106. Penerapan akuntansi tersebut meliputi: Pengakuan, Pengukuran, Penyajian dan Pengungkapan; (2) investasi musyarakah di Bank Syariah X terdiri dari pembiayaan musyarakah permanent dan musyarakah menurun; (3) prinsip pendapatan bagi hasil musyarakah yang diakui oleh Bank Syariah X adalah revenue sharing, maka untuk beban dan biaya yang terjadi dalam pembiayaan musyarakah tidak dapat diakui oleh bank sebagai pengurangan bagi hasil yang akan diterima oleh bank pada periode berjalan, kecuali biayabiaya yang akan terjadi di awal akad pembiayaan; (4) pendapatan usaha investasi musyarakah diakui sebesar bagian mitra pasif sesuai kesepakatan. Sedangkan kerugian investasi musyarakah diakui sesuai dengan porsi dana; dan (5) untuk kerugian yang terjadi pada investasi musyarakah biasanya tidak mengalami nilai yang besar karena yang terjadi pada setia kasus di Bank Syariah X adalah bahwa menurunnya porsi bagi hasil yang diterima bank.

\section{Saran}

Perlakuan akuntansi dan pengakuan pendapatan dalam investasi musyarakah pada Bank Syariah X, dengan tetap konsisten menerapkan perlakuan akuntansi yang sesuai dengan PSAK No.106. Dalam penyajian akuntansi musyarakah, Bank Syariah X seharusnya mengubah pencatatan pembiayaan musyarakah menjadi investasi musyarakah. Jaminan atau angunan dalam investasi musyarakah seharusnya tidak memberatkan nasabah atau debitur. Yaitu dengan memperketat sistem pengawasan proyek atas investasi musyarakah. Investasi musyarakah dan pembiayaan lainnya harus lebih difokuskan dan ditujukan pada sektor Usaha Mikro Kecil dan Menengah (UMKM), sehingga dapat membantu membuka lowongan kerja dan meningkatkan perekonomian masyarakat kecil. Investasi musyarakah dan pembiayaan modal kerja lainnya seharusnya tidak ditujukan hanya kepada usaha atau proyek yang telah berjalan, tetapi juga kepada usaha-usaha yang baru akan didirikan, dengan melakukan pembinaan dan pengajaran usaha. Sehingga akan menciptakan dan melahirkan pengusaha-pengusaha dan enterpreuner baru.

\section{DAFTAR PUSTAKA}

Antonio, S. (2001). Bank syariah dari teori ke praktek. Jakarta: Gema Insani Press.

Muhammad. (2005). Manajemen bank syariah. Yogyakarta: AMP YKPN.

Muhammad. (2004). Prinsip-prinsip akuntansi dalam Alquran. Yogyakarta: UII Press.

PSAK No. 106. (2010). Akuntansi musyarakah. Jakarta: Ikatan Akuntansi Indonesia.

Yusuf, \& Wiroso. (2011). Bisnis syariah. Jakarta: Mitra Wacana Media. 